\title{
Management pay-performance sensitivity, internal cash flow and investment behavior: A test of the free cach flow theory and asymmetric information theory
}

\author{
(C) Higher Education Press and Springer-Verlag 2009
}

\begin{abstract}
The relationship between investment and financing, the two basic components of corporate finance, is of significant interest to researchers and practitioners alike. The free cash flow hypothesis and asymmetric information hypothesis are two important theories to explain the relationship between investment expenditure and cash flow. In this paper, we examine how consistency between the interests of management and shareholders influences investment-cash flow sensitivity, and how the nature of the controlling shareholder influences this relationship, so as to analyze how much the free cash flow hypothesis and asymmetric information hypothesis can explain the practice of investment and financing in China. We use pay-performance sensitivity as a proxy for the degree of consistency between shareholders and management interests. We find that investment-cash flow sensitivity is affected not only by financial constraints that caused by asymmetric information, but also by the shareholder-manager agency problem. It is found that the asymmetric information theory has more explanatory power than the shareholder-manager agency theory. In addition, the relationship between investment-cash flow sensitivity and pay-performance sensitivity is affected by the nature of controlling shareholders. Specifically, in the state-owned enterprises, the investment-cash flow sensitivity is mainly ascribed to information asymmetry problems, but in the non-state-owned enterprises, the investment-cash flow sensitivity mainly results from free cash flow.
\end{abstract}

Translated and revised from Kuaiji Yanjiu 会计研究 (Accounting Research), 2007, (10): 73-81

ZHI Xiaoqiang

School of Business, Renmin University of China, Beijing 100872, China

E-mail: aczxq@sina.com

TONG Pan $(\bowtie)$

School of Accounting, Beijing Technology and Business University, Beijing 100048, China

E-mail: actp@sina.com 
Keywords pay-performance sensitivity, investment-cash flow, free cash flow, asymmetric information

摘要 作为企业理财行为中的两大重要组成部分, 企业投资和融资行为之间的关系 一直备受理论与实务界人士的关注。自由现金流假说和信息不对称假说是解释企业 投资支出与现金流之间关系的两种重要理论。我们考察了管理层与股东利益的拉近 程度对投资现金流敏感度的影响, 以及控股股东性质对这一关系的影响, 从而分析 了自由现金流假说和信息不对称假说对我国企业融投资行为的解释力。我们用业绩 报酬敏感度作为管理层与股东利益接近程度的衡量指标, 发现投资现金流敏感度不 仅受到内外部信息不对称导致的融资约束的影响, 而且受到了股东一经理代理问题 的影响, 但是信息不对称理论的解释力度相对较强。另外, 投资现金流敏感度和管 理层业绩报酬敏感度之间的关系受到公司控股股东所有权性质的影响。具体讲, 在 国有控股公司中, 投资现金流敏感性主要是由于信息不对称问题引起的, 而在非国 有控股公司中，投资现金流敏感性主要是由于自由现金流问题引起的。

关键词 业绩报酬敏感度, 投资现金流敏感度, 自由现金流, 信息不对称

\section{Introduction}

The relationship between investment and financing, the two basic components of corporate finance, is of significant interest to researchers and practitioners alike. According to the capital structure theory of Modigliani and Miller (MM), firms will invest until the marginal returns equal zero (Modigliani and Miller, 1958). As a result, we are not supposed to find any relationship between investment expenditure and internal cash flow. However, the reality is not in line with the perfect assumption of the neo-classical economics. In many cases, investment expenditure is sensitive to internal cash flow. For example, in China, on one hand, some managers abuse enterprise funds and invest in "hot industries" blindly, or even spend all of the cash their enterprise has, resulting in the so-called "over-investment phenomenon" (Zhou, 2002). On the other hand, some enterprises face difficulties in financing. Due to the lack of access to sufficient funds, or extraordinarily high costs of capital, they have to give up a lot of investment opportunities, using the limited cash in investment projects, leading to the so-called "under-investment phenomena" (Liu, 2003). In both cases, enterprise investment expenditure and internal cash flow are closely related.

Theorists have proposed a variety of theories to explain the relationship between investment expenditure and cash flow. For example, Jensen (1986) proposed the free cash flow hypothesis, assuming that managers will deviate from the financial management objectives of maximizing the wealth of shareholders. Managers would rather be committed to expanding their business 
empire and to investing in the projects that are harmful to the wealth of shareholder but beneficial to their own interests. According to this theory, investment expenditure would be influenced by enterprise cash flow. Enterprises having more free cash flow will have more investment expenditure. Myers and Majluf (1984) explained the relationship between investments and financing behaviors based asymmetric information. Given the existence of information asymmetry between internal and external side of an enterprise, external funding providers will demand higher capital premium, which makes the external cost of capital higher than the internal cost of capital. Therefore, enterprises having serious information asymmetry problems will face serious financial constraints. When enterprises face these financing constraints, they will choose investment projects according to their own cash flow situation, or even have to give up some profitable projects, causing under-investment phenomena. According to this theory, investment expenditure will also be influenced by enterprise cash flow. Companies suffering from more serious financial constraints will show a higher sensitivity to investment cash flow. The free cash flow hypothesis pays more attention to shareholders-manager's agency problem, but asymmetric information hypothesis concentrates more on the conflicts between internal investors and external investors. It is an important research topic to test these theories. For example, Vogt (1994), Hadlock (1998), and Broussard et al. (2004) test free cash flow and the asymmetric information theory from different perspectives.

Because the free cash flow hypothesis and the asymmetric information hypothesis explain a firm's investment-cash flow sensitivity from different views, and have different policy implications, we believe that it is of great significance to empirically distinguish the explanatory power of two theories to enterprise practice in China. In addition, because of the special nature in Chinese shareholding structure, it is necessary to explore how the nature of the controlling shareholder influences the relationship between management pay and investment and financing behaviors as well.

In this paper, we will examine how the consistency degree of the interests between management and shareholders influence investment-cash flow sensitivity, and how the nature of the controlling shareholder influences this relationship, so as to analyze how much the free cash flow hypothesis and asymmetric information hypothesis can explain the practice of investment and financing behaviors in China. Our basic idea is as follows:

If the investment-cash flow sensitivity is caused by asymmetric information between internal and external enterprise, we presume that the more consistent the interests between shareholders and management, the stronger the investment-cash flow sensitivity. This is because there has been asymmetric information between insiders (existing shareholders) and external investor (potential funding providers), and the external funding providers will demand risk premium when 
financing into enterprises because of asymmetric information, so that the external cost of capital is greater than the internal cost of capital. Therefore, when financing for investment projects, internal financing would be preferred, demonstrating the sensitivity between investment and cash flow. When the interests of shareholders and management are consistent, the management will choose the investment projects from the point of view of the existing shareholders. It will give priority to internal financing and thus the enterprise investment-cash flow sensitivity will increase.

If the investment cash flow sensitivity is caused by free cash flow, as the interest gap between shareholders and management gets smaller, the investment cash flow sensitivity will be weaker, because the managers have the impulse to keep investing in order to build their own empires. The external funding providers often restrict managers through contracts and other means, hence free cash flow becomes preferred source of funding when managers expand their own empires, demonstrating sensitivity between investment and cash flow. When the interest between shareholders and management is consistent, management has to take the negative consequences of over-investment. Thus the management's abuse of free cash flow will be restrained, and then investments-cash flow sensitivity will decline.

\section{Literature review}

Based on their study purposes, Western scholars' research on investment-cash flow sensitivity can be divided into two categories: One is to study whether investment cash flow is sensitive or not and to examine whether enterprises facing more information asymmetry show stronger sensitivity; the other focus is on verifying whether the asymmetric information theory or the free cash flow hypothesis can be used to better explain the investment-cash flow sensitivity.

\section{1 Investment cash flow sensitivity and financing hierarchy}

This type of literature was originally put forward by Fazzari, Hubberd and Petersen (hereafter referred to as FHP) (1988). ${ }^{1}$ FHP (1988) also leads a wide range academic study on investment-cash flow sensitivity. This type of literature studies how the financial constraints influence investment through the study of the investment-cash flow sensitivity and most of which provides evidence for the existence of the financing hierarchy. Relevant scholars use the characteristics

\footnotetext{
${ }^{1}$ This type of literature includes Hoshi, Kashyap and Scharfstein (1991), Fazzari and Petersen (1993), Gilchrist and Himmelberg (1995), Lamont (1997), and so on. Hubbard (1998) provides a good review.
} 
that reflect the financial constraints of enterprises, such as the dividend payout, size, age, group membership, debt rating, etc, to classify enterprises. They find that enterprises facing greater financial constraints have stronger investment-cash flow sensitivity, and their financing hierarchies are more obvious. Kaplan and Zingales (hereinafter referred to as KZ) (1997) challenge the application of the above conclusions. They classify firms according to their degree of financing constraints, based on quantitative and qualitative information obtained from company annual reports. Contrary to FHP's evidence, $\mathrm{KZ}$ finds the investment decisions of those least financially constrained firms are the most sensitive to the availability of cash flow. Consistent with KZ's findings, Cleary (1999) confirmed that the investment expenditure and internal cash flow of enterprises least financially constrained are most sensitive, which starts a heated debate between FHP (2000) and KZ (2000).

Chow and Fung (2000) tested the financial constraints in different-sized manufacturing enterprises in Shanghai by traditional sales acceleration model. Results show that small manufacturing enterprises have less financial constraints in the financing of fixed investment than the big ones.

By including the variable of internal cash flow into the enterprise investment model of the neo-classical theory, Feng (1999) used 135 listed domestic manufacturing enterprises in 1995-1997 as samples and tested changes in the degree of significance of the model and relevant coefficients after the introduction of new variables. Results show that investment size is influenced not only by the investment opportunities and the cost of capital, but also by internal cash flow. Zheng et al. (2001) classified enterprises according to the proportion of state-owned shares, and found that the lower the proportion of state shares in an enterprise, the less the external financial constraints.

\subsection{The free cash flow hypothesis and asymmetric information theory}

This type of literature focuses on the causation of investment cash flow sensitivity based on testing of the explanatory power of the free cash flow hypothesis and asymmetric information theory. Oliner and Rudebusch (1992) expand FHP's (1988) study in an attempt to reveal the causation of investment-cash flow sensitivity. They choose enterprise age, place of listing and the insiders' stock exchange as proxy variables for information asymmetry, and use the proportion of the shares held by insiders and top 20 shareholders as a proxy for agency cost, and enterprise size for transaction cost. They find evidence to support the hypothesis of asymmetric information. Meanwhile, they find no evidence supporting the transaction cost theory. Vogt (1994) also explored the reason the relationship between cash flow and investment. He found that both the free cash flow hypothesis and the asymmetric information theory 
have explanatory power over investments-cash flow sensitivity. Hadlock (1998) studied how does management ownership (that is generally considered as a symbol of consistency between interests of shareholders and management) influences investment-cash flow sensitivity. No linear relationship had been found between insider ownership and investment-cash flow sensitivity. Specifically, when insider ownership starts from scratch, the investment-cash flow sensitivity increases rapidly. However, when the level of insider ownership reaches a high level, the positive relationship between insider ownership and investment-cash flow sensitivity declines. When the level of insider ownership exceeds certain threshold value, there would be a negative rather than a positive relationship between insider ownership and investment-cash flow sensitivity. Hadlock (1998) explained that the evidence is consistent with the asymmetric information theory, but inconsistent with the free cash flow hypothesis. Broussard et al. (2004) examined how does CEO incentive influence investment-cash flow sensitivity. They used pay-performance sensitivity as a proxy for the degree of consistency between shareholders and management interests. It was found that consistent shareholder-manager interests lead to a reduction in over-investment resulting from free cash flow. However, they do not find the evidence supporting that incentives deteriorate the severity of financial constraints. Using British listed enterprises as samples, Pawlina and Renneboog (2005) found strong investment-cash flow sensitivity. They also found that the sensitivity is mainly caused by the agency cost of free cash flow. Using 397 listed enterprises in Shanghai during 1999-2000 as samples, He et al. (2001) tested the causation of the strong sensitivity between the internal cash flow and investment in Chinese enterprises, and their results support the free cash flow hypothesis.

\section{Theoretical analysis and research assumption}

If the investment cash flow sensitivity is caused by free cash flow, as the gap between the interests of managers and shareholders becomes smaller, managers have to take the negative consequences of over-investment. As a result, their tendency of wasting internal cash flow will be weakened. The investment-cash flow sensitivity will be reduced accordingly. If the investment-cash flow sensitivity is caused by asymmetric information, as the interests between managers and shareholders become more consistent, managers have to take the negative consequences of mis-pricing. As a result, they would be more reluctant to conduct external financing. Enterprises investment will be more dependent on internal capital, which in turn leads to increased investment-cash flow sensitivity.

However, how to measure the consistency degree of interests between 
shareholders and management team? Management ownership is a commonly used proxy variable, as Hadlock (1998) did in his relevant studies. However in China, the level of management ownership is still small, whether it can play an effective role in encouraging managers is doubtful. Following Hadlock's (1998) line, Zhang et al. (2005) assumed that management and major shareholders have the same interests, and use the proportion of the biggest shareholder's share as a proxy for the degree of consistency between management and minor shareholders interests. However, the assumption, namely management team and major shareholder have the same interest, meaning that there is no agency problems between management and shareholders. Such an assumption equates the agency problems between major shareholders and minor shareholders with the agency problems between management and shareholders. In addition, if the level of management shareholding is low, its incentive effects on managers will also be small. Thus, we use management ownership to measure the consistency degree of interests between shareholders and management team.

Broussard et al. (2004) used pay-performance sensitivity as a proxy for the consistency degree of interests between shareholders and management, the pay-performance sensitivity is mainly measured by management ownership and stock options. We believe that this measure is more suitable for the current situation in China. In recent years, a lot of domestic studies on the relationship of management incentive and enterprise performance have revealed a positive and significant relationship between management pay and enterprise performance, such as Zhang, Zhao and Zhang (2003), Song (2004), etc. ${ }^{2}$ It shows that management pay in listed enterprises in China have positive effects on manager incentive to a certain extent. Drawing on these studies, the idea of "pay for performance" has been widely implemented in practice. It is also based on this type of studies that we believe it is practicable to use pay-performance sensitivity as a starting point to study investing and financing behaviors of China's listed enterprises.

How does the management pay-performance sensitivity influence the investment cash flow sensitivity? Does a higher pay-performance sensitivity of the top management team also indicate a higher consistency degree of interests between shareholders and management? As above, improved management pay-performance sensitivity can reduce the interest gap between managers and shareholders and decrease agency costs. However, in the existent empirical research on the relationship between management pay-performance sensitivity and enterprise value or enterprise performance, no consistent conclusions have

\footnotetext{
${ }^{2}$ Earlier researchers, such as Wei (2000) and Li (2000) did not find significant positive correlation between management pay and corporate performance. It might because that the incentives mechanism of listed companies was still immature at that time.
} 
been achieved so far. The classic agency theory (e.g., Holmstrom, 1979) points out that the performance-based pay provides incentives for managers and at the same time brings about the so called "pay risks". Therefore, more incentive does not mean the better. If managers have to face too many risks, they tend to pursue low-risk policies, which usually affect negatively their enterprises' performance. By relating enterprise performance to management pay, the interest gap between shareholders and management can be narrowed because managers will endeavor to improve enterprise performance so as to improve their own pay and to reduce the possibility of gaining low pay.

However, the function mechanism of such an incentive system is also its deficits. As a result, it can not be applied indefinitely to the risk-adverse managers: When faced with too many risks, the degree of the managers' risk aversion will increase, resulting in no investments in projects characterized by both high profits and risks. The point is that manager's attitude towards risks is different form that of shareholders. The latter can spread their risks by diversifying investment portfolios. Therefore, a shareholder's attitude toward risk is more or less neutral. By comparison, managers are more risk-adverse for they can only invest their human capital in one enterprise. If pay-performance sensitivity is too excessive, managers face greater risks, and then they will demonstrate more risk aversion. As embodied in the choice of investment projects, these managers will deviate further away from the interests of shareholders. However, under the pay-performance incentive system, avoiding risk also means reduced pays. Thus too high a pay-performance sensitivity would lead to decline in enterprise performance. The aim of pay contract is to provide an effective incentive mechanism to stimulate managers to take proper measures. The precondition of such an incentive mechanism is to ensure effective scattering of risks. In choosing of the pay contract, one must keep a balance between returns and risks. This shows that improving pay-performance sensitivity has side effects. As sensitivity grows, a manager will be more motivated to create the wealth for shareholders (benefit of increased sensitivity). However, managers' pay risks will also increase as the sensitivity grows. And managers' measures to avoid pay risks will damage the interests of shareholders (cost of increased sensitivity). When pay-performance sensitivity is not so high, benefit of increased sensitivity exceeds cost, leading to enterprise performance improvement (called incentive effects); when pay-performance sensitivity is high enough, the benefit of increased sensitivity may be offsetted or even exceeded by the cost, leading to a decline in enterprise performance (called risk effects). In other words, the pay-performance sensitivity has a threshold point: below this point, there is a positive relationship between performance and the sensitivity; while above the point, the relationship will turn negative. The specific value of the threshold point is related to the specific situation of an enterprise. For example, the risk facing an 
enterprise is an important factor because greater risks make it more likely for managers to take radical actions to avoid risks. As a result, enterprises characterized by greater risks tend to have smaller threshold values.

We can see that higher pay-performance sensitivity does not necessarily mean a higher consistency degree of interests between shareholders and management. Per the analysis of agency theory, a non-linear relationship exists between pay-performance sensitivity and consistency degree of interests between shareholders and the management. When the level of pay-performance sensitivity is low, increase in the sensitivity would reduce the interest gap between shareholders and the management; when the level of pay-performance sensitivity is high, increase in the sensitivity of pay-performance widens the gap.

Based on the above rationale, if investment-cash flow sensitivity is due to free cash flow, as the pay-performance sensitivity increases, investment-cash flow sensitivity will firstly decrease and then increase. If investment-cash flow sensitivity is due to asymmetric information, as the pay-performance sensitivity increases, investment-cash flow sensitivity will firstly increase and then decrease.

Therefore, we propose the following hypotheses:

H1a There is a non-linear relationship between investment-cash flow sensitivity and management pay-performance sensitivity: As the pay-performance sensitivity increases, investment-cash flow sensitivity will decrease first and then increase (the free cash flow hypothesis).

H1b There is a non-linear relationship between investment-cash flow sensitivity and management pay-performance sensitivity: As the pay-performance sensitivity increases, investment-cash flow sensitivity will initially increase then decrease (asymmetric information theory).

In China, there are a large number of state-controlled listed enterprises, whose enterprise governance and financing behaviors are different from non-state-controlled listed enterprises. Xu and Chen (2003) studied the impact the nature of largest shareholder's ownership on the effectiveness of enterprise governance and performance. They found that enterprise performance, ownership structure and governance effectiveness are different if the nature of largest shareholder differs. Non-state-controlled enterprises tend to have higher enterprise value, greater profitability, and higher enterprise governance. Zhang and $\mathrm{Li}$ (2005) brought the ownership structure factor into the investment-cash flow sensitivity analysis. They found out that if the free cash flow hypothesis is correct, investment-cash flow sensitivity should decrease as the proportion of shares held by the biggest shareholder increases; if the asymmetric information theory is correct, investment-cash flow sensitivity should increase as the proportion of shares held by the biggest shareholder increases. Their empirical results showed significant agency problem of free cash flow exist in enterprises controlled by the local government or state-owned enterprises, and enterprises 
ultimately controlled by the central ministries or commissions, non-state-owned entities or other natural persons in China do not have any agency problems of free cash flow. On the contrary, enterprises controlled by non-state-owned legal person have financing constraint problems caused by asymmetric information.

Because enterprises having different controlling shareholders have different agency problems, we hold that the nature of controlling shareholder will affect the relationship between the investment-cash flow sensitivity and management pay-performance sensitivity. Therefore, we propose the following hypothesis:

H2 The relationship between investment-cash flow sensitivity and management pay-performance sensitivity is affected by the nature of controlling shareholder(s).

\section{Research design}

\subsection{Calculation of the pay-performance sensitivity}

In this paper, we use pay-performance sensitivity as the measure of the consistency degree of the interests between shareholders and management. Because the listed enterprises in China do not disclose detail information of management stock options, we can only use management pay and management ownership in calculating the pay-performance sensitivity as follows:

Pay-performance sensitivity = pay performance sensitivity (comp sensitivity) + stock performance sensitivity (stock sensitivity) ${ }^{3}$

In calculating the pay performance sensitivity, the commonly used measure of performance is net income or shareholders' wealth. We believe that shareholders' wealth is more in line with the general idea of this paper than net income for we attempt to use the pay-performance sensitivity to measure the consistency degree of the interests between shareholders and management. In the interests of shareholders, shareholders' wealth is a more direct and accurate indicator than net income. In addition, although the overall level of management ownership is still very low in China, the level of management ownership among different enterprises varies greatly. If using net income as a measure of performance, we can only take into consideration of comp sensitivity, and then the conclusion may be inaccurate. Therefore, to use shareholder wealth to measure enterprise

\footnotetext{
${ }^{3}$ CEOs in western companies have the decision-making power of corporate investment and financing activities. Therefore, Broussard et al. (2004) considered only the CEO pay-performance sensitivity in their study. However, in many Chinese listed companies, CEOs do not have the right to make financial policies, and in some cases, CEOs are not even the most important decision-makers in their companies. Considering China's unique context, we calculate the top management pay-performance sensitivity in this paper.
} 
performance is also beneficial to take a comprehensive consideration of both comp sensitivity and stock sensitivity. Because there are a huge amount of non-tradable shares in Chinese listed enterprises, we use "the total market value considering non-tradable factors" to measure shareholders' wealth.

The calculation formula of comp sensitivity is as follows:

$$
\text { Comp sensitivity }=\left(C O M P_{i, t}-C O M P_{i, t-1}\right) /\left(M V_{i t}-M V_{i, t-1}\right)
$$

$\operatorname{COMP}_{i, t}$ means the annual total pay of all top managers in enterprise " $i$ " in year " $t$ ".

$C O M P_{i, t-1}$ means the annual total pay of all top managers in enterprise " $i$ " in year " $t-1$ ".

$M V_{i, t}$ means the total market value considering non-tradable factors in enterprise " $i$ " in year " $t$ ".

$M V_{i, t-1}$ means the total market value considering non-tradable factors enterprise " $i$ " in year " $t-1$ ".

We use management ownership to measure stock sensitivity.

In this way, we can calculate the sample company's pay performance sensitivity:

$$
P P S(\text { pay performance sensitivity })=\text { comp sensitivity }+ \text { stock sensitivity }
$$

\subsection{Model}

Our empirical test models are mainly based on Broussard's (2004) study. Specifically:

$$
\begin{aligned}
& I=\mathrm{a}_{0}+\mathrm{a}_{1} S+\mathrm{a}_{2} Q+\mathrm{a}_{3} C A S H+\mathrm{a}_{4} C F+\mathrm{a}_{5} L E V+\mathrm{a}_{6} P P S \cdot C F+\mu \\
& I=\mathrm{a}_{0}+\mathrm{a}_{1} S+\mathrm{a}_{2} Q+\mathrm{a}_{3} C A S H+\mathrm{a}_{4} C F+\mathrm{a}_{5} L E V+\mathrm{a}_{6} P P S \cdot C F+\mathrm{a}_{7} P P S^{2} \cdot C F+\mu
\end{aligned}
$$

$\mathrm{a}_{0}$ is a constant. $I$ means a firm's fixed assets investment, equaling to the "cash paid to acquire fixed assets, intangible assets and other long-term assets" in cash flow statement. ${ }^{4} C F$ means a firm's cash flow, equaling to net cash flow from operating activities in cash flow statement. $S$ means a firm's revenue in the

\footnotetext{
${ }^{4}$ Some scholars also used the difference of "net fixed assets (original value of fixed assets + working-in-progress fixed assets + material) + impairment of fixed assets" between the beginning and the end of the present year to measure corporate investment expenditure. However, we believe that the data from balance sheet is not so suitable as the "cash paid to acquire fixed assets, intangible assets and other long-term assets" from cash flow statement, because in China there are too many cases using asset impairment for earnings manipulation. By comparison, the data from cash flow statement are relatively more difficult to manipulate. In the robustness test, we also use the investment expenditure data from balance sheet as the dependent variable and obtain consistent conclusion as using cash flow data, though the value of $R^{2}$ is smaller.
} 
present year. $C A S H$ means a firm's fund stock, equaling to "monetary fund" in the firm's balance sheet at the beginning of the present year. I, CF, CASH and $S$ are the above variables divided by the total assets of an enterprise at the beginning of the present year. ${ }^{5} Q$ means Tobin's $Q$. It is a proxy for the firm's investment opportunities and equals to: (firm's total market value considering non-tradable factors at the beginning of the present year + total liabilities at the beginning of the present year - current assets at the beginning of the present year) / total assets of the enterprise at the beginning of the present year. $L E V$ means a firm's debt ratio at the beginning of the present year. PPS is pay-performance sensitivity. Prime operating revenue and Tobin's $Q$ are used to control the influence of enterprise investment opportunity on the size of enterprise investment expenditure (the coefficient sign is expected to be positive). We use a firm's monetary fund at the beginning of the present year to control the influence of its stack fund on its investment behaviors (the coefficient sign is expected to be positive). In addition, debt ratio at the beginning of the present year is chosen to take into account the influence of a firm's capital structure on investment expenditure (the coefficient sign is expected to be negative).

It should be noted that the investment-cash flow sensitivity is not the ratio of investment to cash flow $(I / C F)$, but the explanatory power of $C F$ on $I$. In the financial constraints literature represented by FHP (1988), scholars have studied whether investment is sensitive to cash flow, as well as what types of enterprises has higher investment-cash flow sensitivity. Their research designs almost all use cash flow to explain the investment expenditure, and examine whether the cash flow is significantly and positively related to investment expenditure after controlling other influencing variables of investment expenditure: If the coefficient of $C F$ is significantly positive, then investment-cash flow is sensitive. In this paper, we examine the relationship between investment-cash flow

${ }^{5}$ According to Chung and Pruitt (1994), Tobin's $Q$ 's calculation formula is as follows:

$$
Q=(M V Z C+B C L I D+B V C L-B V C A) / B V T A
$$

$M V C S$ means the total market value considering non-tradable factors.

$B V L T D$ means the book value of long-term liabilities.

$B V C L$ means the book value of current liabilities.

$B V C A$ means the book value of current assets.

$B V T A$ means the book value of total assets.

The data of "the total market value considering non-tradable factors" is from the CCER database. The formula is, the closing price of A shares at the end of the present year $\times$ the number of tradable A shares + the closing price of $B$ shares at the end of the present $\times$ the number of $\mathrm{B}$ shares $\times$ exchange rate + the closing price of $\mathrm{H}$ shares at the end of the present $\times$ the number of $\mathrm{H}$ shares $\times$ exchange rate + (net assets at the end of last year / the number of total share that day) $\times$ (the number of total share - the number of tradable A shares - the number of $\mathrm{B}$ shares - the number of $\mathrm{H}$ shares). The calculation formula measures the tradable shares value by share price, and measures non- tradable shares value by net assets per share. 
sensitivity and management pay-performance sensitivity, in other words, how pay-performance sensitivity influences the $C F$ 's explanatory power on $I$, rather than how pay-performance sensitivity influences $I / C F$. Therefore, we introduce into the cross-term of $P P S$ and $P P S^{2}$ with $C F$, and $C F$ itself as explanatory variables in the above model so that we can analyze how PPS influences the $C F$ 's explanatory power on $I$ through the degrees of significance and sign of coefficients of $P P S^{*} C F$ and $C F^{*} P P S^{2}$. All the above are used to test the above hypotheses.

\section{Results}

\subsection{Data and sample characteristics}

We examine the listed A-share enterprises in both Shenzhen and Shanghai Stock Exchanges during 1999-2004. All financial and enterprise governance data of the sample enterprises are obtained from the CCER database. In the process of selecting samples, we eliminate: (1) enterprises from the financial industry; (2) enterprises whose investment expenditure ("cash paid to acquire fixed assets, intangible assets and other long-term assets") is less than or equals zero; (3) enterprises with incomplete data of management pay and ownership and other regression variables; (4) enterprises whose pay-performance sensitivities are less than zero. ${ }^{6}$ Finally, we get 2215 sample enterprises.

Table 1 presents the descriptive statistics of related variables of sample enterprises. As shown, median and mean of the ratio of investment expenditure and total assets at the beginning of the present year are $4.3 \%$ and $7.3 \%$, respectively. The median and mean of the ratio of cash flow and total assets at the beginning of the present year are $4.7 \%$ and $5.1 \%$, respectively. The median and mean of the ratio of monetary fund and total assets at the beginning of the present year are $12.4 \%$ and $15.4 \%$, respectively. These results indicate that enterprises use up the total cash flow generated from operations for investment projects, and also use other channels of financing activities for the investment projects. The mean of debt ratio at the beginning of the present year is $46.3 \%$. The median and mean of approximate Tobin's $\mathrm{Q}$ we used to be the proxy for the investment opportunities are 0.895 and 1.046 , respectively. In sample enterprises, the largest PPS is 1.238 2, which means when the shareholders' wealth increases

\footnotetext{
${ }^{6}$ We think that if the company's pay-performance sensitivity is less than zero the company has no "pay for performance" idea, at least no "pay for shareholders' wealth" idea. For these companies, the pay-performance sensitivity cannot be used as a proxy to measure the degree of the interests of management team and shareholders closing. Therefore, we only examine the samples with the pay-performance sensitivity greater than zero.
} 
a 10000 Yuan, the management pay will increase 12382 Yuan. The smallest PPS is $9.83 \times 10^{-10}$, which means when shareholders' wealth increases a 10000 Yuan, the management pay will increase only $9.83 \times 10^{-6}$ Yuan (median $=0.0006$, mean $=0.005$ ).

Table 1 Descriptive statistics for variables in the study (unit: 10000 Yuan)

\begin{tabular}{lccccc}
\hline Variables & Min & Max & Median & Mean & $\begin{array}{c}\text { Standard } \\
\text { deviation }\end{array}$ \\
\hline$I$ & 0.000 & 3.282 & 0.043 & 0.073 & 0.098 \\
$C F$ & -1.450 & 1.171 & 0.047 & 0.051 & 0.110 \\
$S$ & -0.0478 & 8.287 & 0.491 & 0.636 & 0.578 \\
$C A S H$ & 0.000 & 0.824 & 0.124 & 0.154 & 0.120 \\
$Q$ & 0.203 & 30.914 & 0.895 & 1.046 & 0.796 \\
LEV & 0.009 & 10.375 & 0.436 & 0.463 & 0.330 \\
$P P S$ & 0.000 & 1.2382 & 0.0006 & 0.0050 & 0.0345 \\
\hline
\end{tabular}

\subsection{Results}

The second column of Table 2 is the results of model (1). The coefficient of $C F$ is significantly positive, which means that the investment-cash flow sensitivity exists. The coefficient of PPS.CF is insignificantly negative, showing that there is no linear relationship between pay-performance sensitivity and investment-cash flow sensitivity. The third column of Table 2 is the results of model (2). We can see the coefficient of PPS.CF is 1.529 , significant at 0.1 level; the coefficient of $P P S^{2} \cdot C F$ is -1.535 , significant at 0.05 level. These results show that there is a non-linear relationship between investment-cash flow sensitivity and management pay-performance sensitivity. As the pay-performance sensitivity increases, investment-cash flow sensitivity will firstly increase then decrease.

This result supports H1b, namely the main causation of investment-cash flow sensitivity is that the cost of internal capital is less than that of external capital as a result of information asymmetry. Therefore, enterprises give priority to internal financing when investment funds are needed. As the pay performance sensitivity increases, the consistency degree of the interests between shareholders and management grows, and management gives priority to internal financing in the selection of investment funds. When pay-performance sensitivity further improves, management entrenchment effect appears, and managers' investment and financing behaviors will deviate from the interests of shareholders. However, due to the fact that the degrees of significance of the coefficients of both PPS.CF and $P P S^{2} \cdot C F$ coefficient are small, a more appropriate explanation is that investment-cash flow sensitivity is not only affected by financial constraints that 
caused by asymmetric information, but also affected by shareholder-manager agency problem. By comparison, the asymmetric information theory has greater explanatory power.

Table 2 Pay-performance Sensitivity and Investment-cash Flow Sensitivity

\begin{tabular}{lllll}
\hline Variables & \multicolumn{1}{c}{$\begin{array}{c}\text { The whole } \\
\text { sample }\end{array}$} & \multicolumn{1}{c}{$\begin{array}{c}\text { The whole } \\
\text { sample }\end{array}$} & $\begin{array}{c}\text { State-owned } \\
\text { enterprises } P P S>0\end{array}$ & $\begin{array}{l}\text { Non- state-owned } \\
\text { enterprises } P P S>0\end{array}$ \\
\hline constant & $-0.003(-0.122)$ & $-0.002(-0.1)$ & $-0.026(-1.065)$ & $0.086(1.697)^{*}$ \\
$S$ & $0.012(3.568)^{* * *}$ & $0.012(3.512)^{* * *}$ & $0.013(3.403)^{* * *}$ & $0.012(1.2)$ \\
$Q$ & $0.011(3.201)^{* * *}$ & $0.012(3.228)^{* * *}$ & $0.015(3.515)^{* * *}$ & $0.002(3.256)^{* * *}$ \\
$C A S H$ & $0.096(5.599)^{* * *}$ & $0.098(5.662)$ & $0.094(4.837)^{* * *}$ & $0.085(2.355)^{* *}$ \\
$C F$ & $0.212(11.623)^{* * *}$ & $0.203(10.852)^{* * *}$ & $0.185(8.974)^{* * *}$ & $0.32(6.693)^{* * *}$ \\
LEV & $-0.046(-6.11)^{* * *}$ & $-0.046(-6.418)^{* * *}$ & $-0.043(-5.002)^{* * *}$ & $-0.048(-3.042)^{* * *}$ \\
$P P S \cdot C F$ & $-0.206(-0.845)$ & $1.529(1.666)^{*}$ & $1.769(1.865)^{*}$ & $-9.059(-1.793)^{*}$ \\
$P P S^{2} \cdot C F$ & & $-1.535(-1.960)^{* *}$ & $-1.722(-2.138)^{* *}$ & $65.055(2.204)^{* *}$ \\
Adjusted $R^{2}$ & 0.109 & 0.11 & 0.106 & 0.135 \\
$F$-value & 25.63 & 23.840 & 18.158 & 7.229 \\
$N$ & 2215 & 2215 & 1736 & 479 \\
\hline
\end{tabular}

Note: ${ }^{* * *},{ }^{* *},{ }^{*}$ mean significant at confidence level of $1 \%, 5 \%$, and $10 \%$, respectively.

In order to test $\mathrm{H} 2$, the samples are divided into state-owned and non-state-owned enterprises and we conduct regression test on them based on Model (2) to examine whether the coefficients of the cross-terms of PPS.CF and $P P S^{2} \cdot C F$ are significant.

The fourth and fifth column of Table 2 is to test H2. In the state-controlled group, the $P P S \cdot C F$ 's coefficient is 1.769 , significant at 0.1 level; the $P P S^{2} \cdot C F$ 's coefficient is -1.722 , significant at 0.05 level. In the non-state-controlled group, the $P P S \cdot C F$ 's coefficient is -9.059 , significant at 0.1 level; the $P P S^{2} \cdot C F$ 's coefficient is 65.055 , significant at 0.05 level.

We find that the impact of pay-performance sensitivity on the investment-cash flow sensitivity appears to be non-linear in both state-owned and non-state-owned enterprises. However, the impacts are different in the two types of enterprises. In the group of state-owned enterprises, as the pay-performance sensitivity increases, investment-cash flow sensitivity firstly increases then decreases. In the group of non-state-owned enterprises, as the pay-performance sensitivity increases, investment-cash flow sensitivity firstly decreases then increases. These results support $\mathrm{H} 2$ that the relationship between investment-cash flow sensitivity and management pay-performance sensitivity is affected by the 
nature of controlling shareholder. Specifically, in the state-owned enterprises, the investment-cash flow sensitivity is mainly due to information asymmetry problems, but in the non-state-owned enterprises, the investment-cash flow sensitivity is mainly due to free cash flow. It should be noted that our empirical results should not be interpreted as the shareholders-managers agency problem in non-state-owned enterprises is more serious than that of state-owned enterprises. A more acceptable explanation is that the state-controlled listed enterprises tend to be part of a gigantic pyramid ownership structure. Therefore, that the information disclosure requirements introduced by supervising agency are universally applicable for all listed enterprises may not be able to meet the requirements of external funding providers. Therefore, in the state-owned enterprises, investment-cash flow sensitivity is mainly due to information asymmetry.

\section{Conclusion}

In this paper, we examine the relationship between internal cash flow and investment expenditure, that is, the investment-cash flow sensitivity. In order to prove whether the free cash flow hypothesis or asymmetric information hypothesis has more explanatory power for investment-cash flow sensitivity. We start from the management incentive, and examine the influence of pay-performance sensitivity on the investment-cash flow sensitivity. We find that there is a certain non-linear relationship between investment-cash flow sensitivity and management pay-performance sensitivity. On the whole, as the pay-performance sensitivity increases, investment-cash flow sensitivity will firstly increase and then decrease. This shows that financing constraint resulted from internal and external information asymmetry is the main cause of investment-cash flow sensitivity in listed enterprises of China.

The theoretical contributions of this paper are as follows: we verify the pecking order theory from another point of view. In recent years, research on the financing behaviors of China's listed enterprises finds that many listed enterprises prefer external financing to internal one, a finding contrary to the assumption of pecking order theory. Here in this paper, we find that financing constraints have more explanatory power on the relationship between the company's investment expenditure and internal cash flow. This shows that a higher degree of information asymmetry between inside and outside exists in China's listed enterprises, and the asymmetric information makes external funding providers ask for higher risk premium, embodied as listed enterprises' financial constraints.

The practical contributions of this paper are as follows: based on the 
conclusions of this paper, we believe that the current critical problem is to reduce asymmetric information between internal and external enterprises in order to reduce the cost of external financing. In order to reduce the degree of asymmetric information between internal and external, to decrease the risk premium of external funding providers and to cut down differences of the cost between internal and external financing, we think regulatory authority should take some policy, such as strengthen information disclosure management of listed enterprises, improve the accounting rules, enhance audit quality..

It also has some limitations, such as: (1) Since the pay-performance sensitivity of many enterprises is not more than zero, we assume that they do not "pay for performance" and remove them from the final samples. Therefore, our conclusions apply only to enterprises that "pay for performance". In future studies, one could attempt to introduce non-financial proxies to measure the consistency degree of interests between management team and shareholders. (2) Manager tenure, enterprise size and other factors might also affect investment-cash flow sensitivity. However, because of the research theme and space limitations, we do not analyze the effects of these variables. (3) The nature of enterprise ownership may not be a good criterion of classification in the distinction of the nature of controlling shareholders. It is because even enterprises controlled by the state-owned enterprises under the direct control of the central government are very different from each other. For example, in China, a relatively larger number of enterprises controlled by state-owned enterprises in the military industry are propped rather than tunneled by their controlling shareholders, while this might not be the same to those enterprises controlled by other types of state-owned enterprises. Therefore, if a better designed criterion of classification in the distinction of the nature of controlling shareholders could be used, the final conclusions might become more convincing.

Acknowledgements This paper is supported by the National Academic Accounting Talent Project. Special thanks go to the anonymous reviewers for their valuable suggestions.

\section{References}

Broussard J , Buchenroth S A, Pilotte E A (2004). CEO Incentives, cash flow, and investment. Financial Management, 33(2): 51-70

Chow C K, Fung M K (2000). Small businesses and liquidity constraints in financing business investment: Evidence from Shanghai's manufacturing sector. Journal of Business Venturing, 15: $363-383$

Chung K H, StephenW P (1994). A simple approximation of Tobin's $Q$. Financial Management, 23(3): 70-74

Cleary S (1999). The relationship between firm investment and financial status. Journal of Finance, 54(2): 673-692 
Fazzari S M, Hubbard R G, Petersen B C (1988). Financing constraints and corporate investment. Brookings Papers on Economic Activity, (1): 141-95

Fazzari S M, Petersen B C (1993). Working capital and fixed investment: New evidence on financing constraints. RAND Journal of Economics, 24(3): 328-342

Gilchrist S, Himmelberg C P (1995). Evidence on the role of cash flow in reduce-form investment equations. Journal of Monetary Economics, 36: 541-572

Hadlock C J (1998). Ownership, liquidity and investment. RAND Journal of Economics, 29(3): 487-508

Holmstrom B (1979). Moral hazard and observability. Bell Journal of Economics, 10(1): 4-29

Hoshi T, Kashyap A, Scharfstein D (1991). Corporate structure, liquidity, and investment: Evidence from Japanese industrial groups. Quarterly Journal of Economics, 106(1): 33-60

Hubbard R G (1998). Capital-market imperfection and investment. Journal of Economic Literature, 36(1): 193-225

Jensen M (1986). Agency costs of free cash flow, corporate finance and takeovers. American Economic Review Papers and Proceedings, 76(2): 323-329

Kaplan S N, Zingales L (1997). Do investment-cash flow sensitivities provide useful measures of financing constraints? Quarterly Journal of Economics, 112(1): 169-215

Lamont O A (1997). Cash flow and investment: Evidence from internal capital markets. Journal of Finance, 52(1): 83-109

Modigliani F, Miller M (1958). The cost of capital, corporation finance, and the theory of investment. American Economic Review, 48(3): 261-297

Myers S, Majluf N (1984). Corporate financing and investment decisions when firms have information those investors do not have. Journal of Financial Economics, 13: 187-221

Oliner S D, Rudebusch G D (1992). Sources of financing hierarchy for business investment. The Review of Economics and Statistics, 74(4): 643-654

Pawlina G, Renneboog L (2005). Is investment-cash flow sensitivity caused by the agency costs or asymmetric information? Evidence from the UK. Working Paper, European Corporate Governance Institution

Vogt S C (1994). The cash flow/investment relationship: Evidence from US manufacturing firms. Financial Management, 23(2): 3-20

冯巍 (Feng Wei) (1999). 内部现金流和企业投资: 来自我国股票市场上市公司财务报告的证据 (Internal cash flow and corporate investment: The evidence from the financial reports of listed companies in China's stock market). 经济科学, (1): 51-57

何金耿，丁加华 (He Jin'geng, Ding Jiahua) (2001). 上市公司投资决策行为的实证分析 (Empirical analysis on investment decision making behaviors of listed companies). 证券市 场导报, (9): 44-47

李增泉 (Li Zengquan) (2000). 激励机制与企业绩效: 一项基于上市公司的实证研究 (Incentive mechanisms and firm performance: an empirical study on listed company). 会计研究, (1): 24-30

刘曼红(Liu Manhong) (2003). 中国中小企业融资问题研究 (Research on Financing of Middle and Small Enterprise). 北京: 中国人民大学出版社

宋德舜 (Song Deshun) (2004). 国有控股、最高决策者激励与公司绩效 (State holding, incentives of top decision-maker and firm performance). 中国工业经济, (3): 91-98

魏刚 (Wei Gang) (2000). 高级管理者激励与上市公司业绩 (Top management incentive and performance of listed company). 经济研究, (3): 32-39

徐晓东, 陈小悦 (Xu Xiaodong, Chen Xiaoyue) (2003). 第一大股东对公司治理、企业业绩的影 响分析 (Analysis on the largest shareholders impact on corporate governance and performance). 经济研究, (2): 64-74 
张俊瑞, 赵进文, 张建 (Zhang Junrui, Zhao Jinwen, Zhang Jian) (2003). 高级管理层激励与上市 公司经营绩效相关性的实证分析 (Empirical analysis on the relevance of top management incentives and the performance of listed companies). 会计研究, (9): 29-34

张翼, 李辰 (Zhang Yi, Li Chen) (2005). 股权结构、现金流与资本投资 (Ownership, cash flow and investment). 经济学季刊, (1): 229-246

郑江淮, 何旭强, 王华 (Zheng Jiangwei, He Xuqiang, Wang Hua) (2001). 上市公司投资的融资 约束: 从股权结构角度的实证分析 (Financial constraints in the listed companies investment: Explanation from the views of structure of equity). 金融研究, (11): 92-99

周立 (Zhou Li) (2002). 自由现金流代理问题的验证 (Test of free cash flow problem). 中国软 科学, (8): 43-47 